\author{
A.N. Karybayeva ${ }^{(D)}$, A.D. Kurmanaliyeva \\ Al-Farabi Kazakh National University, Kazakhstan, Almaty, \\ e-mail: Karybaeva.ainur@gmail.com
}

\title{
PSYCHOLOGY OF RELIGION IN THE SYSTEM OF RELIGIOUS STUDIES
}

This article provides a general analysis of the study of the psychology of religion. The aim is the disclosure of the causes of its occurrence, development and interaction with other aspects of the history of mankind and mutual influence in the human mind. The article reveals two terms that are still often confused, although they denote various phenomena - its the psychology of religion and religious psychology. Unfortunately, the main reason for the prevailing confusion of these concepts is the very little attention paid until recently to the study of the phenomena of psychology in general and the phenomena of religious psychology in particular. Meanwhile, the development problems psychology of religion today is particularly important. Historically and psychologically, religion is very closely, especially at the first steps of mankind, intertwined with other forms of social consciousness: morality, art, science. She had a tremendous impact on the whole life of mankind and entered into mores and customs. Moreover, no other science can replace it. Knowledge of the psychology of religion, as we have seen, allows to better understand the past and present relations of religion and life.

Key words: psychology of religion, religious psychology, consciousness, religion, personality.

А.Н. Карыбаева, А.А. Құрманалиева

Әл-Фараби атындағы Қазақ ұлттық университеті, Қазақстан, Алматы қ., e-mail: Karybaeva.ainur@gmail.com

\section{Аінтану жүйесіндегі дін психомогиясы}

Бұл мақалада Аін психологиясын зерттеу мәселесіне жалпы та^дау беріледі. Мақсаты ретінде оның пайда болу, даму және адамзат тарихының басқа тараптармен өзара іс-қимыл және адам санасында өзара іс-қимы^ себептерін ашу көрініс табады. Мақалада әлі күнге дейін жиі қатар қолданысқа түсетін, бірақ түрлі құбылыстарды білдіретін, дін психологиясы және діни психологиясы секілді екі термин ашылып қарастырылады. Өкінішке орай, бұл ұғымдардың ауысуының басты себебі жақын уақытқа дейін жалпы психология құбылыстарын және Аіни психология құбылыстарын зерттеуге аз көңі^ бөлінгені. А^ Аін психологиясының мәселелерін зерттеу қазір аса маңызды мәнге ие болып отыр. Тарихи және психологиялық тұрғылан, әсіресе аламзаттың алғашқы қадамдары кезінде, дін қоғамдық сананың басқа түрлерімен, әсіресе, мораль, өнер, ғылыммен өте тығыз байланыста болған. О^ адамзат өміріне үлкен әсер етіп, әдет-ғұрыптарға еніп кетті. Айта кететіні, басқа ғылым оны алмастыра алмайтыны. Біз көріп отырғанымыздай, Аін психологиясын білу дін мен тұрмыстың өткен және нағыз байланыстарын терең түсінуге мүмкіндік береді.

Түйін сөздер: дін психологиясы, діни психология, сана, Аін, тұлға.

\author{
А.Н. Карыбаева, А.А. Курманалиева \\ Казахский национальный университет имени аль-Фараби, Казахстан, г. Алматы, \\ e-mail: Karybaeva.ainur@gmail.com
}

\section{Психология религии в системе религиоведения}

В данной статье проводится общий анализ изучения психологии религии. Целью выступает раскрытие причин его возникновения, развития и взаимодействия с Аругими сторонами истории человечества и взаимовлияния в сознании человека. Также в статье раскрываются два термина, которые до сих пор нередко смешивают, хотя они обозначают различные явления это психология религии и религиозная психология. К сожалению, главной причиной бытующего смешения этих понятий является крайне малое внимание, уделявшееся до недавнего времени изучению явлений психологии в целом и явлениям религиозной психологии в частности. МежАу тем разработка проблем психологии религии сейчас приобретает особо важное значение. Исторически и психологически религия очень тесно, особенно при первых шагах человечества, 
переплелась с другими формами общественного сознания: моралью, искусством, наукой. Она оказала громаАное влияние на всю жизнь человечества и вошла в нравы, обычаи. Причем никакая другая наука не может ее заменить. Знание психологии религии, как мы увидим, позволяет глубже разобраться в прошлых и настоящих связях религии и быта.

КАючевые слова: психология религии, религиозная психология, сознание, религия, мичность.

\section{Introduction}

Religion is a form of social consciousness. Its origin, the laws of development and extinction are studied by the history of religion and sociology. Religion is a complex social phenomenon that has a number of sides: organization, cult, religious ideology and religious psychology. The first three sides are quite different in different times and in different nations. They have created, developed and continue to develop are now servants of cults, people who have made a profession of religion. There are two terms that are still often confused, although they denote various phenomena. Psychology of Religion - a section of the public (social) psychology who studies social and psychological phenomena related to the field of religion. In other words, the psychology of religion is a branch of science, which lies at the intersection of psychology and sociology, ethnography and history of religion. Religious psychology is a socio-psychological phenomenon related to the field of religion, which is the object of study of the branch of science - the psychology of religion (Ugrinovich D.M. 1986: 24). Mixing these concepts to some extent stems from the fact that the word "psychology", as we know, is embedded two different meanings: psychology as a science that studies the laws of the emergence, development, and formation of psychic phenomena, and psychology as a storehouse of feelings and ideas of a separate group of people singled out for some basis (for example, peasant psychology, philistine psychology, etc.) (Vygotsky L.S. 2005: 36). Unfortunately, the main reason for the prevailing confusion of these concepts is the very little attention paid until recently to the study of the phenomena of psychology in general and the phenomena of religious psychology in particular. Meanwhile, the development problems psychology of religion today is particularly important. Moreover, no other science can replace it. There is another feature of religious psychology, which determines the importance of not only the development of the psychology of religion, but also its widespread popularization. The fact is that an integral part of religious psychology is not only religious beliefs, but also a religious feeling that strengthens these beliefs. To reveal the reasons for the emergence of a religious feeling means to help those experiencing it overcome this feeling in themselves. Historically and psychologically, religion is very closely, especially at the first steps of mankind, intertwined with other forms of social consciousness: morality, art, science. She had a tremendous impact on the whole life of mankind and entered into mores and customs. The task of science is not only to evaluate this fact, but also to reveal the reasons for its occurrence, development and interaction with other aspects of the history of mankind. Therefore, the task of the psychology of religion is to reveal these causes and mutual influences in the human mind. To open in order to effectively deal with religious remnants. Similar social conditions are not always unambiguously reflected in both individual and social consciousness. So, in the VI century, in similar social conditions, the Byzantine Empire and the state of the Sassanids - the Persian kingdom existed nearby. But Byzantium was Christianity, for example, marriage between brother and sister is a sin, which is terrible to think, for who on earth - the death penalty, and in the "other world" eternal torment. In Persia, such a marriage was the most pleasing to God, ideal. In medieval Christian Europe, death penalty was punished for bigamy, and nearby in the East, the more wives a Muslim had, the more he was honored (Wundt V. 2002: 112).

\section{Main part}

Knowledge of the psychology of religion, as we shall see, makes it possible to better understand the past and present relations of religion and life. As you know, Engels called religion «a fantastic reflection of reality», and Lenin - «sick with imagination», distinguishing between the social, historical and epistemological roots of religion. Marxist epistemology is a dialectical-materialistic theory of knowledge (Platonov K.K. 1967: 27). It is closely connected with the psychological science that studies psychic phenomena and thus reveals the essence of knowledge as a reflection of the world. Theologians have always tried to prove the «eternity» of religious feeling. Adherents of Judaism, Christianity and Islam at the same time kept repeating about the eternity of faith in one God, supposedly inherent in man at all times and among all peoples. Speaking about the current state of the psychology of religion, it should be noted that its heyday, which fell in the USA and Europe in the 1890-1920s, was 
quickly replaced by the decline of the 1930-1950s. - a phenomenon which, with a light hand B. Beit Hall, called the "rise and fall" of the psychology of religion (Belzen J. 2010: 399). These dynamics is quite understandable as the socio-historical circumstances of the period (in particular, the two world wars and others) and the height of the methodological crisis in the science of psychology and the inner logic of the development of the discipline itself. The «Renaissance» of the psychology of religion was not so swift and ubiquitous: it stretched for several decades and led to the formation on the world scientific arena of many schools and approaches, often radically different in theoretical and methodological grounds, as well as in views on the subject and specificity of the psychology of religion as research program. Erich Neumann (1905-1960) notes that in modern society the old religious and ethical values have lost their authority over a man, and it is for the individual hazard due to the loss of life goals. Religion is rooted in the collective unconscious, it supports the integrity of society, although many of the archetypes associated with it are dominant. Mystical experience is important for a person, because it is a constant «surprise» in front of oneself and the world. Today, there are several theories that, along with the previous ones, can be considered dominant. First of all, this is the role theory of religion of Yalmar Sunden (1908-1993), who in 1959 proposed studying religiousness as an assignment of a role (Cronbach A. 1978: 201). The second authoritative theory is attribution: religious systems offer individuals a set of religious attributions to give meaning to phenomenon in life. In the framework of this theory, such well-known psychologists of religion as Bernard Spilka, Philip Robert Shaver and several others conducted their research. Religion as a phenomenon of cultural life was dealt with by representatives of the so-called "cultural psychology" (D. Wulf, J. van Belsen). After the representatives of humanistic psychology of religion within the framework of this approach continues to be perceived as an effective psychotherapeutic tool that integrates identity and helps her find a solution to problems encountered (Belzen J. 2010: 401). For Western psychology of religion, two approaches to solving this problem are typical: either positivistic, or frankly idealistic or theological. The positivist point of view prevailed in the first decades of the psychology of religion in the United States and Europe. A number of studies it has been suggested that as part of the psychology of religion should abandon the question of the truth or falsity of religious beliefs, because this issue is outside the scope of psychology as a science. Thus, the
French psychologist T. Flurnois (1854-1920) wrote: «Religious psychology refrains from any sentence regarding these phenomena and eliminates any argument about the possibility of the existence of the invisible world and its nature» (Hall S. 1923: 78). This thought was repeated many times and later. For example, the Belgian psychologist A. Godin in his report to the XV International Psychological Congress in Brussels (1957) stated that one of the principles of the «positive» psychology of religion is the refusal to resolve the issue of the existence of transcendental. The English psychologist R. Thouless, describing the positivist approach in the psychology of religion, wrote: «This approach proceeded from the idea that the essential function of the psychologist was to observe and study religious phenomena without resorting to judgments about their truth and not trying to determine their truth» (Barrett $J$. 2011: 231). On the one hand, such views, especially in the early stages of the existence of the psychology of religion, contributed to its dissociation from theology, from openly fideistic concepts, and emphasized the scientific status of this discipline. However, one should not forget that positivism dissociated itself from both theology and philosophical materialism. The positivist psychologist who studied religion did not directly deny the existence of the supernatural, he only limited his task to the study of psychological processes and states of believers, stating that the solution of the so-called "metaphysical" problems is the task of philosophy or theology. Therefore, the initial cautious attitude of theologians and leaders of the church towards the psychology of religion was soon replaced by its «acceptance», which was accompanied, on the one hand, by emphasizing its «borders», on the other hand, it was recognized as useful for the practical work of a priest and a preacher.

Some Western psychologists at the beginning of the century expressed the idea of the psychology of religion as a science that could «reinforce» the idealistic and even religious worldview. Thus, American psychologist James Pratt wrote that the psychology of religion should not touch upon «metaphysical problems», but nothing prevents it from «supplying philosophy with material that it can use to support a religious view of reality» (Starbuck E.1899: 146). As we recall, in her James refers to the purest examples and the most striking manifestations of religious experience (James W. 1910: 52). However, he uses several empirical methods: refers to the data from the surveys Edwin Starbuck, refers to the autobiographical documents of religious literature. Following James, Starbuck and Leuba used 
primarily quantitative research methods - the results of mass surveys, statistical data (Leuba J. 1909: 42). In the European tradition, from Jean-Martin Charcot to Sigmund Freud, qualitative research methods dominated: description of pathological cases, observation, analysis of self-observation, the gradual use of projective techniques (Hall S. 1982: 26). Religious consciousness exists on two levels: ideological - theology, religious philosophy, ethics and social doctrine of the church - and socio-psychological - a really functioning consciousness of the whole mass of believers, their religious ideas, experiences, stereotypes of the psyche and behavior. The study of the socio-psychological level of religious consciousness is especially important for understanding the real changes that occur in the spiritual life of people (Coe G. 2015: 64). Without a scientific study of the psyche of modern believers, those problems and contradictions that are characteristic of their consciousness, it is impossible to build atheistic education correctly. Therefore, the scientific, Marxist psychology of religion has not only theoretical, but also practical significance. It is directly related to the practice of atheistic education of workers in a socialist society. We do not know how the initiations took place in the Stone Age, but we know that among Australians and more advanced nations, the initiation of adolescents into war is connected not only with the ritual of his trials, but also with the rituals of introducing him to the secrets of the tribe. The initiate to being told previously hidden from him the sacred totemic myths, and in the more complex forms of religion - the myths of the tribal gods and heroes. In the consciousness of adolescents undergoing initiation, a turning point occurs, experienced as a kind of sacred sacrament. It is quite understandable that when a teenager grows old and performs initiation rituals with a new generation, his emotional memory will restore these feelings, and he will sincerely believe that he conveys to the young warrior something mysterious and sacred that he himself received earlier. In combination with the magical faith and under the influence of the differentiation of the community, the allocation of privileged leaders, sorcerers and especially experienced masters in it, and the manifestation of the idea of spirits among the Melanesians, for example, this belief takes the form of the idea of a certain faceless supernatural power - mana. Therefore, for some Melanesians, the sacrament of initiation is complicated by the ritual of initiation into a secret male union, reflecting the further decomposition of the primitive communal system and the emergence of a caste order. In Judaism, Islam and Christianity, the introduction of religion from adolescence was postponed to the first weeks after the birth of the child, but many initiation rituals remained: casting spells, circumcision, cutting off hair, immersion in water, etc.

A person is a specific person, a subject of cognition and transformation of the world, society consists of personalities, and all the experience of mankind is accumulated in it (Pratt J. 1988: 435). But man is not only a person, but also an organism. Personality - a person as a carrier of consciousness. And therefore, the personality, as well as consciousness, is integral, and it is possible to «break» it into separate elements and substructures only conditionally, for the purpose of studying. What is meant by the structure of religious consciousness, speaking here, of course, about individual consciousness, and not about public consciousness? Consciousness is the highest form of the psyche, peculiar only to man. Therefore, there is no difference between the «human psyche» and the «consciousness». The concept of «religious psychology» - as a feature of the psyche of a religious person - is no different from the concept of «religious consciousness». Consciousness, like personality, is the same for a particular person. After all, we always artificially separate the various sides and forms of concrete consciousness, «tearing», as Engels said, from interconnection, from integral consciousness (Guntrip H. 1949: 77). Because something impossible for the religious consciousness it is possible for a human consciousness as a whole. Meanwhile, the concept retains its significance even without any connection with religion. In our opinion, a positive answer to this question is beyond doubt. This need is objectively inherent in people living in any social system, including the socialist one.

Human consolation in our society is an important factor that can prevent a person from turning to religion as a way of consoling the illusory. Harvey Cox interviewed members of non-traditional groups and sects in the United States about the reasons for joining these groups. One of the main reasons, according to the respondents, was the lack of friendship and warmth in communication between people, which they hoped to fill in religious communities. So, for example, M.G. Pismanic writes: "A third of the believers we examined answer the question: "What do you particularly value in religion? » - answered: «Consolation is in trouble». According to sociologists, almost $90 \%$ of believing Baptists in one form or another speak of the importance of the «consolatory» function of religion for them: religion, they say, helps to endure troubles, grief, reduces the fear of death, etc. (Frankl W. 2008: 89). The 
need for the removal of negative emotional states, for emotional discharge, is especially urgently felt by people at the time of a life crisis, the loss of loved ones, etc. Exactly in these situations that funeral, memorial, and other rites are necessary, which, according to V. Veresaev, are an established, familiar form of realization of collective experiences (Slobodchikov V. 2007: 95). But emotional discharge is necessary for a person not only at critical moments in life. In the process of the formation of Christianity, the evolution of the cult went along the lines of its «spiritualization», which implied, in particular, the abandonment of previous material sacrifices. Christianity denies sacrifices. However, the doctrine of the so-called good deeds among Catholics and Orthodox Christians presupposes obligatory material support for the church, donations to churches and monasteries, and these «good deeds» are considered by the church as an important condition for the «saving the soul» of the Christian. A kind of «substitute» of previous sacrifices in the Christian cult system are the rituals of lighting candles and lamps in front of icons and other «sacred» images. All these ritual forms ascend to pre-Christian sacrifices and in many respects fulfill their functions. In the process of the formation of Christianity, the evolution of the cult went along the lines of its «spiritualization», which implied, in particular, the abandonment of previous material sacrifices. Prayer as a specific religious rite was formed on the basis of primitive magical conspiracies and spells, i.e. the so-called verbal magic (magic of word). Prayer originally was part of the sacrifice his verbal component. This is evidenced by many of the facts collected by ethnographers. For example, among the Negidals (a small nation living in the Amur region), sacrifices were usually accompanied by verbal appeals to the «spirits-owners». On a generic prayer Elder, proceeding to cut the cooked head of an elk - a victim to the spirits of heaven, said: «Have pity on us, heaven, sun, moon, prayer! ». According to the famous ethnographer E. Taylor, on the Papuan island of Tanna, where the souls of deceased ancestors are worshiped, who patronize the growth of fruits, the leader of the tribe after the first fruits are offered pronounces the following words: "Compassionate father! This is food for you, eat it and give it to us! ». Subsequently, prayer separated from sacrifice and became an essential component of the cult of many religions, including Christianity. In Christianity, theologians distinguish between several types of prayers, depending on what feelings and aspirations of the prayer they express. But we should not underestimate the role of prayer in the maintenance and reproduction of religiosity. Prayer has been and remains a powerful means of psychological consolation, removal of negative experiences. It is characteristic that solitary prayer almost eliminates non-religious motivation, which is why many sociologists consider it an important sign of true religiosity. In moments of doubt about the truths of religious faith, a person turns to prayer. This is how a former Catholic Priest I. Ragauskas describes his prayers in those days when he doubted the truth of the Catholic faith: "O God Jesus, if you are truly here, hear me. Here I am, your minister, I am turning to you in the most difficult hour of my life ... You see how sincerely I seek truth, but I don't know where it is ... The more I reflect, the more I tear myself away from the faith from you, O God ... So save me now, Jesus! ». The American Psychologist J. Leuba distinguished between two types of prayers (Winnicott D. 1953: 89). The psychological basis of the first type is a kind of «deal with God», asking him for certain blessings and, accordingly, a promise to fulfill all the divine instructions given to believers through the church. The purpose of the prayers of the second type is «communication» with God, rapprochement and even dissolution of the believer in God. These ideas of Leuba deserve attention, since here important psychological features of cult actions characteristic of mystics and religious ecstatics are recorded. Indeed, the main purpose of their prayers and other religious activities is to achieve a feeling of proximity to the supernatural (in monotheistic religions - to God), merging with it. From the point of view of psychology, the state of mysticism at this moment is usually characterized as a state of ecstasy, i.e. as a state of maximum stress and depth of experience, disconnecting the individual from the surrounding reality and switching his mental energy on illusory objects. In the Western psychology of religion, the problem of using religion for psychotherapeutic purposes is actively discussed. One of the active propagandists of this idea was an American Protestant priest and psychologist A. Boyzen. From his point of view, mental disorders and religion have one common source - the crisis situation in the life of an individual. But religion, according to Boyzen, is a «constructive» way out of this situation, which is beneficial for the individual, and psychosis is destructive, negative. Hence his conclusion about the importance of religion as an important means of treatment of mental patients. Another American psychologist, W. Oates, states that «a thorough study of the role of religion in the prevention and treatment of mental illness shows the importance of the preventive and therapeutic role of a priest in the life of his parishioners». He is supported by S. Hiltner, 
who believes that the achievements of the psychology of religion should be put at the service of religious instruction and education and widely used by priests in their practical activities. In a number of capitalist countries, a special branch of the psychology of religion has long taken shape - the so-called "pastoral psychology" (Slobodchikov V. 2007: 143). Pastoral psychology is studying the ways and means of the most effective influence of priests on the consciousness of believers. It is very fashionable and «clinical studies» psychotherapeutic effect of the impact of religion on patients with neuroses. Magazines and television advertise the healing effects that religion supposedly has on such patients. The psychiatric qualification of psychopathological «religious» experiences does not cause fundamental difficulties. Scope of the spiritual competence of the psychiatrist is not included, but for a more meaningful study of the problem seemed necessary to describe its characteristics depending on the psychopathology of options. The immediate object of the study was the "semantic layer subjective image of the world», which affects the religious human existence. Studied patients with schizophrenia spectrum disorders, consider themselves Orthodox. Control Healthy Believers. The trichotomous principle applied to specific patients substantiated the division of the entire contingent into 3 groups:

1) is experiencing a religious theme is entirely a manifestation of the disease;

2) patients whose faith was formed before the onset of the disease, but religious experience entered the picture of the disease (attack);

3) whose faith and illness "did not touch" (Voskresensky B. 2017: 124).

The results demonstrated differences in the organization of semantic fields by groups. The more unfavorable the course of the disease, the more disorganized the "religious image of the world" turned out to be. These data theoretically substantiated some psychotherapeutic recommendations. Patients of the first group maintenance, cultivation of religious experiences is not shown, at least during an exacerbation of the disease. In the second special activities related to faith, church life (to which such people often seek) is also undesirable, but participation in community activities on a common basis is possible. There are no restrictions for the third group. We also evaluated such a peculiar manifestation of depersonalization as the patient's perception (localization) of the soul. The healthiest people this issue is not specifically specified. Patients with a favorable course of the disease also often found it difficult to answer the question about the location of the soul or placed it in the thorax. When the disease worsened, the soul could move, for example, into the solar plexus. In other cases, the soul became a «shell» around the body, traveled in space and time, the planets were endowed with the soul. Culturally and historically, the ideas of reincarnation and panpsychism may correspond to this. Other parallels between norm and pathology can be noted. So for some spiritual practices (for example, Hesychasm), the formlessness of experiences, a peculiar change in the «I am» are characteristic: «a person does not remain the same, but he remains himself». He emphasizes that, despite the synergistic nature of the Hesychast process, there is no experience of external influences. The disease, as it develops, activates the most ancient forms of organization of mental processes. Religiosity as such unfolds in a completely different space. So, faith carries significant psychotherapeutic and rehabilitation potential and thereby it turns out in a certain respect stronger than the disease.

\section{Conclusion}

So, we see that the psychology of religion is a dynamic project, largely dependent on the development of psychological science as a whole, but in the last few decades it has been gaining more and more independence. Several key points make this project relevant. First of all, the modern psychology of religion can be an experimental science - to the extent that it wants to remain a science and psychology. It is possible that it is not a full-fledged pilot, but rather a quasi-experimental type of research, but rather about quasi-experimental types of research, but they also allow testing hypotheses and tracing hypothetical causal relationships. Special direction, which only proves its right to existence, but perhaps it will be very promising, - is the use of special gadgets that enable us to derive an empirical study of religious phenomena from the laboratory to the real world and explore the everyday side of religiosity: mobile applications, electronic watches, cameras and camcorders, portable physiological condition monitoring devices, etc. This allows us not to confine ourselves to the study of self-reports and texts and directly observe human behavior in the context of their daily activities, which gives researchers a unique opportunity not to be present. At the same time, the psychology of religion cannot be an exclusively experimental science: after its maternal discipline, it should take advantage of interdisciplinary methods, since they allow maintaining the external validity of research 
and better encompass social phenomena. Psychologists, excluding theoretical reflections, creating a mass of statistical data, and not a complete picture. The specifics of empirical work in psychology and the diversity of approaches indicate that modern psychology of religion cannot be an armchair science and the occupation of individuals - for rel- evant projects need multidisciplinary team, equipment, common interests and a single categorical apparatus. At the same time, religion psychologists must avoid both experimental reduction and speculative theorizing, which ignores historical realities, cultural specifics, and particularities of different religions.

\section{References}

Barrett, J.L. (2011) «Cognitive Science of Religion: Looking Back, Looking Forward», Journal for the Scientific Study of Religion 50 (2). $213 \mathrm{p}$.

Belzen, J.A. (2010) «Religion and Self: Notions from a Cultural Psychological Perspective», Pastoral Psychology 59 (4). 190 p.

Coe G.A. (2015) The Psychology of Religion. Chicago: University of Chicago Press. 185 p.

Cronbach, A. (1978) «The Psychology of Religion: A Bibliographical Survey», The Psychological Bulletin 15 (12). 180 p.

Frankl V. Suffering from the meaninglessness of life: relevant psychotherapy. Novosibirsk: Siberian University. Publishing House, 2008. 178 p.

Guntrip, H. (1949) Psychotherapy and Religion. London: Independent Press. 212 p.

Hall, S.G. (1923) Jesus, the Christ, in the Light of Psychology. New York, D. Appleton. 320 p.

Hall S.G. (1982) «Moral and Religious Training of Children», Princeton Review. New Series IX. 125 p.

James V. The diversity of religious experience / trans. from English V.G. Malakhieva-Mirovich and M.V. Chic; under the editorship of S.V. Lurie. M .: journal. «Rus. Thought», 1910. 183 p.

Leuba, J.H. (1909) The Psychological Origin and the Nature of Religion. London: Archibald Constable. 312 p.

Platonov K.K. Psychology of religion. Facts and thoughts. M .: Politizdat, 1967. 90 p.

Pratt J.B. (1988) «The Psychology of Religion», The Harvard Theological Review 1 (4). 165 p.

Slobodchikov V.I. Christian psychology in the system of psychological knowledge // Psychology. Journal of the Higher School of Economics. 2007.V. 4. No. 2. 132 p.

Starbuck, E.D. (1899) The Psychology of Religion. New York: Scribner. 156 p.

Ugrinovich D.M. Psychology of religion. M .: Politizdat, 1986. 144 p.

Voskresensky B.A. Some clinical aspects of the problem of «religiosity and mental disorders» - Religiosity and clinical psychiatry: Materials of the First Moscow International Conference, Moscow, 2017. 146 p

Vygotsky L.S. The historical meaning of the psychological crisis // LS Vygotsky Psychology of human development. M .: Publishing house Sense; Eksmo Publishing House, 2005. 120 p.

Winnicott, D.W. (1953) «Transitional Objects and Transitional Phenomena», International Journal of Psycho Analysis. 216 p.

Wundt V. Psychology of peoples. M .: EKSMO - TERRA FANTASTICA, 2002. 160 p. 